\title{
Micro-invasive glaucoma surgery (MIGS): a review of surgical procedures using stents [Corrigendum]
}

Pillunat LE, Erb C, Jünemann AGM, et al. Clinical Ophthal-

mology. 2017;11:1583-1600.

Throughout the paper iStent inject ${ }^{\circledR}$ was incorrectly listed as iStent inject or iStent ${ }^{\circledR}$ inject. Throughout the paper iStent Supra ${ }^{\circledR}$ was incorrectly listed as iStent Supra or iStent ${ }^{\circledR}$ Supra.

\section{Publish your work in this journal}

Clinical Ophthalmology is an international, peer-reviewed journal covering all subspecialties within ophthalmology. Key topics include: Optometry; Visual science; Pharmacology and drug therapy in eye diseases; Basic Sciences; Primary and Secondary eye care; Patient Safety and Quality of Care Improvements. This journal is indexed on

\section{Dovepress}

PubMed Central and CAS, and is the official journal of The Society of Clinical Ophthalmology (SCO). The manuscript management system is completely online and includes a very quick and fair peer-review system, which is all easy to use. Visit http://www.dovepress.com/ testimonials.php to read real quotes from published authors. 